purifies the air. But when the rain first commences to fall, the number of bacteria increases. This Dr. Miquel explains by supposing that many of the first drops of rain evaporate-the atmosphere not being saturated with vapour - and deliver up the bacteria they hold to the air in the neighbourhood of the earth. Later on the air is saturated with vapour, and the bacteria floating in it are carried down to the ground in the drops of rain, and by this means the air is purified.

Investigation of the organisms contained in rain show that the rain which first falls in a shower and that which falls after a period of dry weather contain far larger numbers of bacteria than that which falls at any other times. Under such circumstances 200,000 microbes per litre is not an unusual quantity. 'The rain which falls during the warm months of the year-in summer and autumn - contains more microbes than that which falls in winter and spring. During the year 1883-84 the lowest monthly average was 1000 per litre in November, and the highest 6980 per litre in September. As the rain derives its organisms from the air which it purifies in its descent, we should expect the seasonal variations in the number of contained organisms in air and rain to correspond closely-as in fact they do. It is important to note that the organisms exist in the rain to a larger extent in the form of germs than in the adult state. Of 100 bacteriform organisms found in rain, on an average 60 are micrococci, 25 bacilli, and 15 true bacteria. But the numbers here given are subject to great variation in different falls of rain : the bacilli may be more numerous than the micrococci, the true bacteria being almost always fewest in number. Dr. Miquel calculates that during a year at Montsouris 4,000,000 of bacteria are carried down in the rain to each square metre of surface. This number, though not probably representing anything like the real figure, demonstrates that rain is a powerful agent in diffusing aërial bacteria and fungi. We have yet much to learn as to the part these organisms undoubtedly play when diffused into the soil, in altering or rearranging its component parts or constituents so as to render it more fit for sustaining vegetable life and growth.

The methods and apparatus employed by Dr. Miquel in his researches are very fully explained, and contrasted with other methods--especially those employed by Dr. Koch and other German observers-in terms that are not exactly those which a strict regard for international courtesy would dictate. It is somewhat of a reproach to bacteriologists that their leading authorities in all countries appear unable to keep clear of controversies which are conducted with an acrimony and animus more instructive than seemly. International jealousy would appear to lie at the root of much of this evil, and is plainly discernible in the writings of some of the ablest masters of the science.

\section{THE RECENT VOLCANIC ERUPTION IN NEW ZEALAND}

U NTIL the report of a trained geologist has been received we must be content with the narratives, often conflicting, of the surveyors and of the Press correspondents who hurried to the scene of the great catastrophe that has recently devastated the wonderland of New Zealand. In the meantime, however, it is possible from the various accounts to trace the leading features of the eruption, and to note their resemblance to those of other recorded volcanic outbursts. It is impossible not to be struck with the analogy between the phenomena exhibited last June in New Zealand and those that accompanied the great Vesuvian eruption in the first century of our era. In both instances a mountain which had never been known to be an active volcano suddenly exploded with terrific violence, filling the air with ashes and stones. At each locality there were the premonitory earthquakes, the thick black pall of volcanic cloud hanging over the mountain, the descent of dust, sand, and hot stones, the discharge of mud, with, so far as known, no outflow of lava, and the overwhelming of an inhabited district under a deep covering of loose volcanic debris.

In a region so subject to earthquake shocks as that which crosses the centre of the North Island of New Zealand in a north-east and south-west direction, it was natural that no special attention should have been given to any greater frequency or violence of the shocks before the date of this volcanic eruption. But no doubt facts bearing on this subject have been noted by local observers and will in due course be published. From the newspaper accounts, indeed, there would appear to have been various precursory indications which in the light of subsequent events may not have been without importance. It is said, for instance, that the extinct volcano Ruapehu, the highest peak in the North Island, which since the discovery of New Zealand has never been known to manifest any activity, began to steam at the top some three weeks before the eruption. A fortnight previous to the catastrophe a wave 3 feet high suddenly arose on the Lake Tarawera, lying at the foot of the mountain of the same name, and in the very focus of the subsequent disturbance, and washed the boats out of the boat-houses. Doubtless there were other premonitory symptoms, besides earthquake activity, of the approaching event, though only a few days before their destruction, the famous White and Pink Terraces were visited by a party of tourists who observed no unusual vigour in the hot springs there, nor any indication whatever that these fairy-like deposits were so soon to be the theatre of violent volcanic energy.

About half an hour after midnight on the morning of June ro the earthquake shocks that are familiar to the inhabitants of the Lake District assumed an altogether unusual vigour and frequency. At the settlement of Wairoa, which is about five miles from the warm lake and sinter terraces of Rotomahana, the ground shook violently for an hour or more, the more powerful shocks following each other at intervals of about ten minutes. The alarmed inhabitants, startled from sleep, ran out of their houses or clung to each other inside for mutual assistance and encouragement. At last, a few minutes after 2 a.m., a shock of exceptional severity was followed by a deafening roar, and suddenly what is described as a "pillar of fire" rose up from the crest of the mountain range some five or six miles eastward on the opposite side of Lake Tarawera. The top of Mount Tarawera (about 2000 feet high) had been blown into the air, leaving a huge chasm on the flank of the mountain. The glow of the white-hot lava in the interior ruddied the sky for miles around. Thousands of blocks of glowing lava described as "fire-balls" were shot into the air. The canopy of dark ashes that soon gathered over the mountain and spread out for miles around became the theatre of a violent electrical storm. It seemed to be torn asunder with incessant flashes of lightning, and the continuous peals of thunder, mingling with the bellowing of the volcano, increased the terror of the night.

That an eruption should ever take place from the three huge truncated cones that frown over Lake Tarawera was not regarded by geologists as a future probability. They had been extinct even from the times of early Maori tradition. To their solitary and mysterious summits the natives had probably for centuries been accustomed to carry their dead. The bones of many successive generations lay bleaching on that high lonely plateau, which had thus come to possess a peculiar sanctity in the eyes of the Maoris, who would not willingly allow a white man to approach it. Not only were these great cones to all appearance extinct, but the volcanic action of the whole district was of that type of waning energy which geolo- 
gists have called the " solfatara stage." New geysers might break out, rivalling or even surpassing those already active in the district, and the orifices of eruption might shift from place to place, involving considerable local disturbance in their transference; but no one anticipated that in this district a great explosion, like the most gigantic outburst of Vesuvius, was likely to occur.

The magnitude of the explosion may be inferred from

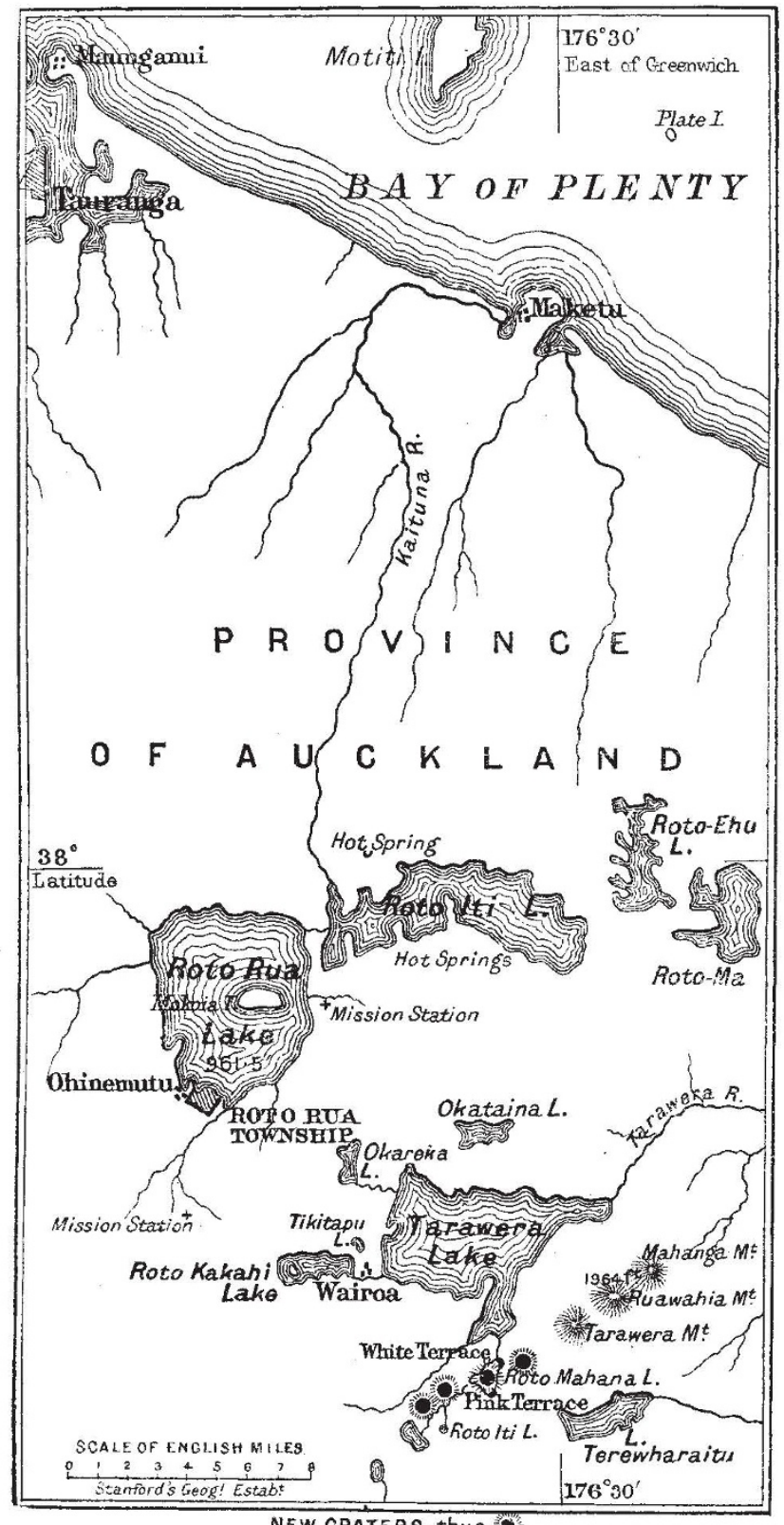

NEW CRATERS, thus

several facts which appear in the newspaper reports. An observer at New Plymouth, on the west side of the island, 150 miles from the scene of the disaster, saw the column of ashes rising far into the air, and computed its height to be not less than 22,000 feet. The noise of the explosion is said to have been heard at Christ Church, a distance of some 300 miles. The ashes fell over a vast area of land and sea to the north and east of the vent of discharge. Vessels sailing even 130 miles away found the air thick with fine dust, which settled on their decks. Near the scene of the explosion the depth of accumulated ashes, still quite hot, was found by some adventurous explorers, seeking to succour the poor Maoris, to be not less than 20 feet. At a distance of 30 or 40 miles the deposit was still several inches thick, so stupendous must have been the amount of rock blown into powder by the great explosion of Tarawera.

The materials ejected from that mountain appear to have consisted mainly of loose fragments of lava, cinders, ashes, and fine dust, with vast quantities of steam, while not improbably hot water and mud issued from the flanks of the volcano. So far as can be gathered from the narratives, there was no emission of lava, though, from the "flames" and "fire-balls" so generally referred to, it may eventually be found that molten lava flowed out somewhere on the sides of the mountain.

Not far from the base of the volcanic cone of Tarawera lay the warm lake and sinter terraces of Rotomahana. The treacherous nature of that district has been often remarked-its steam-vents, boiling pools, hot steaming soil, and eruptive geysers, not always remaining in the same places, but apt with no warning to break out at fresh points. This weird locality has been involved in the volcanic disturbances of the region. The famous terraces have been blown into the air, and fragments of their sinter have been picked up among the dust and ashes of the surrounding country. The lake on the borders of which they stood has been ingulfed. On their site scores of mud-cones are vomiting forth stones and mud, and hurling clouds of steam into the air. New vents for the escape of steam and the outflow of volcanic mud have been opened all over the country, and the aspect of the landscape has been entirely changed. A scene of fairylike beauty has been transformed into one of loathsome desolation. Even if the volcanic activity calms down and the sinter springs can recommence their work of deposition, many generations must pass away before they can build up again such terraces as have been destroyed. The new features of the country will no doubt still prove attractive to tourists, but the marvellous staircases of $\mathrm{Te}$ Tarata are a dream of the past.

Among the features of the eruption on which it is to be hoped that light will be thrown by the more detailed investigations of experts are the source and behaviour of the mud that overwhelmed the settlement of Wairoa. From the narratives of the survivors, showing that the houses were crushed in from above, the mud seems to have descended through the air upon the district, mingled with ashes and stones. Rain fell during the night, but the mud could hardly have been formed in the air by the mixing of the rain and dry ashes. It appears to have come down as liquid mud and was no doubt ejected as such from some neighbouring vent. The orifice of eruption could scarcely have been the great cone of Tarawera; more probably there were many vents not only at Rotomahana, but nearer to Wairoa, by which a large amount of mud was discharged over the surrounding district.

Another question that will no doubt receive careful consideration relates to the movements of the air during the time of the eruption. Barometric observations at Rotorua and at places on the opposite sides of the island will be of much interest. From the newspaper accounts it is clear that a great atmospheric disturbance accompanied the eruption. About an hour after the great explosion a gale suddenly arose in the Rotorua and Wairoa district, and blew with such fury as to uproot and prostrate immense numbers of trees, and to strip off leaves and branches from those that were left standing. At Rotorua the direction of the hurricane was towards the scene of volcanic activity, as if the air were being drawn into the vortex caused by the explosion. A few hours later the gale as suddenly ceased and then ashes began to fall, borne northwards by some upper current of air. We 
have yet to learn how far these atmospheric movements were connected with or independent of the eruption.

There are some excellent geologists in New Zealand who have now a rare opportunity of investigation. No mud-eruptions at all comparable in magnitude to those of this summer in New Zealand have ever been known. The connection of these with the explosion of Tarawera, the relation of the latter to the lava-reservoir inside, the nature of the so-called "flames" and "pillar of fire" so conspicuous on the night of the eruption, the sources of the "fire-balls," and many other details, offer a wide and most interesting field for the colonial observers. Geologists all over the world will await with much interest the publication of their investigations.

ARCH. GEIKIE

\section{NOTES}

THE honour of knighthood has been conferred on Mr. Philip Magnus, the head of the City and Guilds Technical Institute at South Kensington.

LAST Saturday a banquet was given to M. Chevreul by French students to celebrate the one hundredth anniversary of his birth.

THE death is reported on June 22 of Dr. H. F. Hance at Amoy, at which place he was Her Majesty's consul. Although no independent work bears Dr. Hance's name, he has done more than any other man to make us acquainted with the flora of China, both of the empire and of the British colonies. His contributions to botanical literature are to be found in periodicals, very largely in Trimen's Fournal of Botany; and the number of species described by him for the first time is very great. $\mathrm{He}$ was a contributor to the herbaria at the British Museum and at Kew. It is to be hoped that his herbarium will be brought to London and deposited where it can be consulted, and his types readily compared with those of other authors. A full synonymic catalogue of all the known Chinese plants is now in course of publication by Messrs. Forbes and Hemsley, and is greatly needed.

UNDER the energetic management of Dr. Adolph Bastian the Administration of the Berlin Royal Ethnological Museum has commenced to publish a series of original communications explanatory of the varied contents of that superb collection. According to the present programme four parts of about 60 large octavo pages each, with two or more plates of illustrations, will be issued yearly by the Berlin publisher, W. Spemann, at the price of 16 marks, or 4 marks each. Judging from the three parts, which have already appeared for the year 1885-86, the series promises to develop into a vast encyclopæedia of anthropological subjects. Many of the communications constitute in themselves more or less exhaustive essays on special branches of ethnology, and to some of them a peculiar value attaches, because contributed by the collectors or observers themselves. Such, for instance, is the paper on funeral rites in the Pellew Islands, contributed to the first number by the traveller, Kubary, who has spent many years in the Occanic regions, and made a special study of the Polynesian and Micronesian islanders. The same number contains a report on Richard Rohde's expedition to the Paraguay and Brazil (Matto Grosso) in $1883-84$, followed by the traveller's account of the Bororo and Guato tribes in the Upper Paraguay basin. Of great value is Dr. O. Finsch's paper in Part II. on the ethnological collections from the South Sea Islands, some 3000 objects, of which more than half found their way to the Berlin Museum. The importance of securing specimens from this region before it is too late is well shown by the experience of this traveller, who on revisiting New Britain in I884-85 was no longer able to procure several objects which were readily obtainable three years previously. Others, such as wood-carvings, are now " manufactured" in New Ireland "for the trade," the natives finding good customers amongst the crews of passing ships. This paper is followed by the explorer Grabowski's description of nearly 200 objects from South and East Borneo, many extremely rare, if not quite unique. Dr. Bastian concludes a characteristic essay at the end of Part III. with the words: "So walte ein Jeder seines Amtes,-und uns ist die Aufgabe zugefallen,-Das rechtzeitig in Sicherheit zu bringen, was morgen schon verloren sein mag."

In the July number of the American Fournal of Science, Prof. Rockwood, jun., of Princeton, publishes a paper (the fifteenth of the series) on the earthquakes of North and South America for the year 1885 . The writer again attempts to assign to each earthquake a grade of intensity, based where possible upon the character of the physical phenomena reported. Where no such information was available the estimate is based on the phraseology of the original report, taking into account the probable intensity of an earthquake in the locality in question. There is, as Prof. Rockwood recognises, a large element of uncertainty in these estimates, "but at least they are the best that can be made now, and better than any one else could make at a later date and without access to the original reports." This last consideration alone appears to us to justify the attempted classification. A large proportion of the American earthquakes of the year occurred in California, and accordingly a small outline earthquake map of that State for the year is given. The whole list contains 7 r items : 34 belong to the Pacific coast of the United States, 9 to the Atlantic States, 8 to the Canadian provinces, 5 to New England, 3 to the Mississippi valley, 5 to South and 2 to Central America.

We may also take this opportunity of referring to the same writer's annual account of the progress in vulcanology and seismology for 1885 , published in the Smithsonian Report. Most of the incidents recorded, and papers and other publications referred to have from time to time been described or reported in our own columns, and it is therefore only necessary to say that in this as in previous years the summary shows great care and industry, and should be an invaluable vade mecum to all interested in the study of these phenomena.

Tre United States Commissioners are still continuing their labours in the direction of acclimatising flatfish to American waters, which are nearly as well suited to the Pleuronectidie as English waters. Several attempts have been made to transmit them from our shores alive, but hitherto with little success. Information has, however, reached us to the effect that fifty soles during last month were sent by the Derby Museum authorities at Liverpool, twenty-five of which reached their destination alive. Prof. Baird, the Chief Commissioner, states that the fish are in a thriving condition and feed well. They have been placed in a suitable habitat at Washington Station, and are being watched with special care. The soles, which are about three inches long, were transmitted in glass globes attached to the ceiling of the cabin of the s.s. Britannic. This method minimises the risk of injury to the fish through the oscillation of the vessel, as the receptacles, being swung, move backwards and forwards with the motion of the steamer. The National Fish Culture Association intend forwarding to America another consignment of flatfish next month in order to assist the operations of the Commissioners. The sole is a very delicate fish, and cannot withstand the strain of protracted journeys, which makes it very difficult to transmit.

Messrs. J. B. LippincotT AND Co. have in the press a "Manual of North American Birds," by the eminent ornithologist, Prof. Robert Ridgway, Curator of the Department of Birds, Smithsonian Institution, Washington, D.C. The author has had 